\title{
Process Standardization of Whey Protein Enriched Spiced Quarg Cheese
}

\author{
D. D. Patange ${ }^{1 *}$, S. V. Shinde ${ }^{1}$, D. S. Chavan ${ }^{2}$, D. K. Kamble ${ }^{1}$ and C. V. Memane ${ }^{1}$ \\ ${ }^{1}$ Division of Animal Husbandry and Dairy Science, College of Agricyulture, \\ Kolhapur-416004, India \\ ${ }^{2}$ Department of Food Tech., Shivaji University, Kolhapur, India \\ *Corresponding author
}

\begin{tabular}{|c|}
\hline $\begin{array}{l}\text { K e y w o r d s } \\
\text { Qurg cheese, WPC, } \\
\text { Ginger, Cumin, } \\
\text { Storage study }\end{array}$ \\
\hline Article Info \\
\hline $\begin{array}{l}\text { Accepted: } \\
\text { 15 May } 2018 \\
\text { Available Online: } \\
\text { 10 June } 2018\end{array}$ \\
\hline
\end{tabular}

A B S T R A C T

The present study was undertaken with the prime objective to know the organoleptic and physico-chemical qualities of WPC enriched spicesd quarg cheese. WPC was added at 5, 10,15 and $20 \%$ of quarg. The products were evaluated for sensory attributes, physicochemical qualities and afterward assessed for its storage stability. The maximum score for colour and appearance, body and texture, spreadability and overall acceptability was recorded for the product containing $10 \%$ WPC, while the maximum flavour score was recorded to $5 \%$ WPC. To know the combine and interaction effect of ginger and cumin on quarg cheese, ginger @ 3,4 and 5\% and cumin @ 1 and 2\% were added in WPC inriched quarg. The product was evaluated for sensory and physico-chemical qualities. The maximum score $($ score $=8.03$ ) for body and texture and spredability (score $=7.83$ ) were recorded to the product containing $10 \% \mathrm{WPC}, 2 \%$ ginger and $1 \%$ cumin. The $\mathrm{pH}$ of quarg cheese was significantly $(\mathrm{p}<0.05)$ decreased with increasing level of ginger and cumin. The optimized spiced quarg cheese contained $11.87,18.54,4.47,1.41 \%$ fat, protein, lactose and ash respectively. The WPC enriched quarg cheese without addition of ginger and cumin was acceptable up to $15^{\text {th }}$ days while samples added with ginger and cumin was acceptable up to $20^{\text {th }}$ days at refrigerated storage condition.

\section{Introduction}

All over the world people consume fermented foods not only for nutrition but also for its potential health benefits. Fermented milk contains all the milk components modified through the process of fermentation by lactic acid bacteria. The conversion of part of lactose to lactic acid during fermentation, destabilize the casein by lowering the $\mathrm{pH}$ and their by enhance the digestability (Prajapati et al., 2017). The process of fermentation results in production of antibacterial effect such as organic acids, bacteriocins, hydrogen peroxide, fatty acids etc, which are said to impart health benefits by dealing with the pathogens. Cheese is the generic name for group of fermented milk based food products, produced in a great range of flavour and forms throughout the world (Fox et al., 1992). FAO records the cheese production in India at 1500 tones at against the global production of 7832 tones in 2016 (www.faostat.fao.org). Cheese is held in high esteem in the food system and in food chain owing to its excellent portability, long life and good nutritive value (Bhongale et al., 2016). There are more than 2000 varieties of cheese, although many have little 
difference. The most popular varieties of cheese are cheddar, mozzarella, feta, cottage and quarg cheese. Quarg is a natural, unripened, fresh cheese produced on a large scale in Germany and is very popular there. It is manufactured by acid coagulation of milk by proper bacterial cultures (e.g. Steptococcus cremoris and Leuconostoc citrovorum) with a small rennet addition for better separation of the protein coagulum from the whey and thus better yields. It is produced in a variety of fat contents, ranging from an essentially fat free type to a variant with as much as $40 \%$ fat in the dry matter. Quarg generally used as spread and often used as an ingredient for sandwiches, salads, cheese cake. It has a typical slightly sweet flavour and taste which not generally accepted by the Indians. Indian likes slightly spicy, salty, sour and astringent flavor. In traditional quarg cheese making, casein forms the curd structure, while the whey protein is lost in the whey. It means quarg is lacking in whey protein and lactose. As utilization of whey protein is essential in human diet because it contains $\alpha$ lacto albumin, $\beta$ lacto globulin, immunoglobulins and lactoferrin have exhibited a number of biological effects having various effects on the function of digestion and anti-carcinogenic activity. Whey protein contains about $35-75 \%$ protein (Menzies et al., 1988) and has ability to displace eggs, milk protein and offer significant benefits in terms of microbiological quality, product safety and shelf life. The advantages of incorporating of WPC into cheese have increased the nutritional value, cheese yield and especially in the low fat cheese, sensory improvement, besides it puts whey to good use (Hinrichs, et al., 2001).

Spices are used in comparatively small quantities to improve the palatability of the food products. Ginger and cumin are most common spices traditionally used in Indian culinary dishes particularly spread; due to the pungent taste and interesting aroma of ginger and flavoring properties of cumin. Considering the nutritional importance of WPC and use of ginger and cumin in traditional dishes or spread, quarge cheese has been prepared by incorporating them.

\section{Materials and Methods}

\section{Materials}

Fresh buffalo milk was procured from Dairy Farm, Agriculture College, Kolhapur and standardized to $4.5 \%$ fat while, LF-40 starter culture was procured from National centre of dairy culture, NDRI, Karnal (India) and rennet enzyme make CHR HANSEN Ltd. Mumbai was utilized. To improve the whey protein content in quarg cheese, whey protein concentrate i.e. 70 (WPC) was procured from Modern dairy, Karnal having 4.2\% moisture, $67 \%$ whey protein, $16 \%$ lactose and $6.5 \%$ minerals. Whereas, for improvement in the flavour of experimental cheese rhizome ginger (Zingiber officinale) of Mahim variety, cumin (Cuminum cyminum) and common iodized salt were procured from Kolhapur market. Before use the light outer skin of ginger was scrapped off using a blunt knife and cut into tiny pieces and finally made ginger paste, while cumin was crushed into fine powder and sieved through 20 mesh.

\section{Methodology}

\section{Protocol for qurg cheese making}

Buffalo milk standardized to $4.5 \%$ fat and $9 \%$ $\mathrm{SNF}$ was heated at $85^{\circ} \mathrm{C}$ for $5 \mathrm{~min}$ in a $\mathrm{SS}$ cheese vat (size $25 \times 16 \times 16 \mathrm{~cm}$ ) and cooled to $28 \pm 1^{\circ} \mathrm{C}$, inoculated with $1 \% \mathrm{LF}-40$ starter culture and placed for a period to lower down the $\mathrm{pH}$ to 6.3. Renneting was done (rennet @ $0.5 \mathrm{~g} / 100$ liter of milk). Thereafter the vat content was left undisturbed for curd setting in incubator at $31^{\circ} \mathrm{C}$, which took around 14-16 
hrs. The coagulum was then cut using $1 / 3$ inch cheese knives and it was again left undisturbed for about $5 \mathrm{~min}$ and then coagulum was allowed for cooking. The temperature of the coagulum was slowly and gradually increased to $60-65^{\circ} \mathrm{C}$. At last cooked curd was cooled to room temperature and hanged in muslin cloth for 4-6 hrs for dewheying. Thereafter WPC, ginger, cumin and salt were added in curd at desired level and blending of total mass was carried out in a planetary mixer (SPAR make, Taiwan). The quarg is then filled in sterilized glass container and stored at $6 \pm 1^{\circ} \mathrm{C}$.

\section{Optimization of spiced quarg cheese:}

To improve the whey protein content in quarg cheese, WPC-70 was added @ 5, 10, 15 and 20 $\%$ in it whereas, the ginger paste was added @ 3,4 and $5 \%$ and cumin powder was added @ 1 and $2 \%$ of quarg. The best levels of WPC and combine effect of ginger paste and cumin powder were optimized on the basis of sensory evaluation.

\section{Storage study of developed Quarg cheese:}

The best optimized level of WPC, ginger and cumin obtained in experimentation were used for further storage stability studies of quarg cheese and compared with WPC added quarg cheese without addition of ginger and cumin. The quarg cheese samples were packed in sterilized glass container of $100 \mathrm{~g}$ capacity and stored at $6 \pm 1^{\circ} \mathrm{C}$ for storage studies. The samples were evaluated after 5 days interval for changes in sensory attributes, chemical properties and microbial load. The treatment details were as follows.

CS- WPC enriched quarg cheese without ginger and cumin

GS- WPC enriched quarg cheese with ginger and cumin

\section{Analytical Methods}

\section{Sensory analysis}

The product for sensory characteristics viz. colour and appearance, body and texture, spreadability, flavor and overall acceptability was evaluated by semi trained panel of judges from the staff of the Institute by using 9 points hedonic scale as per Amerine et al., (2013). The spreadability was asses by the panelist using a piece of bread slice to spread the product.

\section{Proximate analysis}

The proximate estimation for moisture, ssprotein, fat, lactose, ash, total solids was done as per A.O.A.C (1999).

\section{Microbiological analysis}

The standard plate count, yeast and mould count and coliform count were enumerated as per procedure described in A.O.A.C (1999) using standard media of Hi-Media make.

\section{Statistical Analysis}

After collection of the research data, it was tabulated and statistically analyzed in respect of completely randomized design (CRD) and Factorial Randomized Block Design (FRBD) with equal replications (Snedecor et al., 1994).

\section{Results and Discussion}

\section{Effect of WPC on sensory attributes of quarg cheese}

The perusal of data from table 1 showed that the score for colour and appearance of quarg cheese were significantly $(\mathrm{p}<0.05)$ lowest at the highest concentration of WPC. The score for first four treatments were at par with each other. It was observed that with increase in 
WPC in quarg, the score was improved with $10 \%$ addition of WPC. The highest score (7.5 \pm 0.08 ) was obtained by quarg wherein WPC was added @ $10 \%$. For this treatment judges made the comments that the product had shining and slight creamy colour with uniform appearance. The lowest score of $\mathrm{W}_{4}$ was associated with the comments of pronounced greenish colour as well as dry appearance of the product may be due to inbuilt colour of WPC, which was exhibited at higher level. Increase in dryness of khoa with increased level of WPC was also reported by Sudhir (2002). The present finding was also agreed with the finding of Dewani and Jayaprakasha (2002) for studies on pedha. It was observed that the score for body and texture was increased from the level of $\mathrm{W}_{0}$ to $\mathrm{W}_{2}$.

However, the increase in score was at par with each other $\left(\mathrm{W}_{0}, \mathrm{~W}_{1}\right.$ and $\left.\mathrm{W}_{3}\right)$. The quarg prepared by addition of WPC at $10 \%$ possessed soft body and recorded highest score for body and texture (score $7.43 \pm 0.15$ ) followed quarg prepared by addition of WPC at $5 \%$ (score $=7.10)$. The product with 15 and $20 \%$ of WPC did not liked by the judges, as these products possessed comparatively compact and too firm body and highly porous or coarse texture. Thapa and Guptha, (1996) and Jayaprakasha, (2000) revealed the same result, with increase in level of WPC, decrease the moisture and gave a higher firmness to the product. Contradictory findings were reported by Paul et al., (2004) in biscuits enriched prepared with WPC wherein they observed with increase in WPC in biscuit there was decrease in the firmness and consistency and an increase in the cohesiveness of dough.

It was clearly illustrate from the table 1 that the spreadability score was in between "like slightly" to "like moderately" for the treatments $\mathrm{W}_{0}, \mathrm{~W}_{3}$ and $\mathrm{W}_{4}$. The lowest score was for $\mathrm{W}_{4}$ might be because of water holding capacity of WPC which resulted in too firm body and resist to spread the quarg. It is worthy to mention that at lowest level of WPC the product was too soft and had weak body may be because of less TS of the product and thus resulted in decrease in spreadability score. At increasing the level of WPC the graininess is observed in the product which resist to spread the product, the present finding are supported by the Sudhir (2002) report. The quarg prepared by addition of WPC at 5 and $10 \%$ was recorded statistically merely equal score for flavour i.e. clean and mildly acidic with slightly cooked. The sample without having WPC recorded significantly low flavour score than sample treated as $\mathrm{W}_{1}$ because of having pronounced sour flavour of the product. Whereas, at increased level of WPC the flavour scores were decreased might be because of having heat induced and lipidprotein compounds and bland flavours of WPC.

Further, Thapa and Gupta (1996) also reported that higher levels of WPC addition imparted milder flavour to the processed cheese foods. This finding also supported by Pinto et al., (2007). Quarg prepared by addition of $10 \%$ WPC scored significantly highest (score 7.60) for overall acceptability. It was also observed that at higher proportion of WPC (15 and 20 $\%)$ significantly $(\mathrm{p}<0.05)$ decreased in overall acceptability score for quarg.

The present finding are in accordance with the study of Beena et al., (2012) who reported that mean overall acceptability scores of more than 7.5 for biscuit sample containing $10 \%$ WPC indicated the commercial scope for manufacturing good quality biscuit. David (2015) also successfully utilized WPC in the development of dietetic Kulfi which had a wider scope in the market as per health and nutritional quality is concerned. From the above results the $10 \%$ level of WPC in quarg cheese was optimized and continued in further study. 
Effect of WPC on physico-chemical properties of quarg cheese

The maximum fat content (13.00\%) (Table 2) was recorded for quarg cheese prepared without addition of WPC $\left(\mathrm{W}_{0}\right)$. As the WPC level increased, the fat content were significantly ( $\mathrm{p}<0.05)$ decreased. Raju (2004) also reported that with the incorporation of WPC in the biscuits resulted in decrease in fat content. The highest protein content was recorded in quarg cheese prepared without addition of WPC. It was found that as the WPC level increased the protein content were significantly $(p<0.05)$ increased. The present finding was confirmed with the report of Pinto et al., (2007) where they revealed that increase in WPC level also increased in protein content in cheese spread. The protein in the present investigation was much higher than the quarg prepared by (Yadav, 2015). Further, as the WPC level increased, ash and lactose content, were increased significantly $(p<0.05)$. The maximum ash and lactose content were recorded in the quarg cheese prepared by addition of $20 \%$ of WPC. The total solid content of quarg cheese was ranged from $26.82 \%\left(\mathrm{~W}_{0}\right)$ to $43.97 \%\left(\mathrm{~W}_{4}\right)$. As the WPC level increased the total solid was also increased significantly $(\mathrm{p}<0.05)$. Quarg cheese blended with $20 \%$ was recorded the highest titrable acidity in product.

\section{Combine effect of ginger and cumin on sensory attributes of quarg cheese}

Based on the preliminary trial the quantity of ginger and cumin to be optimized was finalized. Accordingly ginger was added @3 $\left(\mathrm{G}_{1}\right), 4\left(\mathrm{G}_{2}\right)$ and $5\left(\mathrm{G}_{3}\right) \%$ whereas, cumin was added @1 $\left(\mathrm{C}_{1}\right)$ and $2\left(\mathrm{C}_{2}\right) \%$ of quarg cheese containing $10 \%$ WPC. The maximum score (8.03) for colour and appearance was recorded to the product containing $4 \%$ ginger and 1 per cent cumin (Table 3). Hailu et al., (2014) also reported the similar finding in cheese made by adding ginger crude extract which had lower score for colour than that made by using Camel Chymosin (CC). Maximum body and texture score (7.62) was recorded in the product containing $3 \%$ ginger and $1 \%$ cumin.

The overall mean of body and texture score was 7.09. It was also observed that with increasing level of ginger and cumin score was significantly decreasing for body and texture score. This might be because of ginger become fibrous and cumin was in coarse form. Raising the level of ginger juice to 5 per cent caused decreased in score of body and texture of Ice cream in comparison to control sample (Agrawal, et al., 2015).

The optimum spreadability score (7.83) were found in the quarg cheese prepared by the addition of ginger and cumin at 3 and $1 \%$ respectively. The maximum flavour score (7.82) was recorded in the $\mathrm{G}_{2} \mathrm{C}_{1}$ product. The addition of ginger had significant effect on overall acceptability score of quarg cheese. The maximum score was recorded for the product contained $4 \%$ ginger and $\%$ cumin.

Combine effect of ginger and cumin on physico-chemical properties of quarg cheese

The maximum fat content $(11.83 \%)$ was recorded for quarg cheese prepared by addition of $5 \%$ ginger and $2 \%$ cumin while, the highest protein content was recorded in quarg cheese prepared by addition of $4 \%$ ginger and $2 \%$ cumin(Table 4). It was found that as the cumin level increased the protein content were significantly $(\mathrm{p}<0.05)$ increased. The maximum lactose content was found in the quarg containing $3 \%$ ginger and $1 \%$ cumin. As the ginger and cumin level increased ash content was also increased significantly $(\mathrm{p}<0.05)$.whereas, the combine effect of ginger and cumin on ash were nonsignificant. 
Int.J.Curr.Microbiol.App.Sci (2018) 7(6): 1349-1358

Table.1 Effect of WPC on sensory attributes (score)* of quarg cheese

\begin{tabular}{|c|c|c|c|c|c|}
\hline WPC level & \multicolumn{5}{|c|}{ Sensory attributes } \\
& $\begin{array}{c}\text { Colour and } \\
\text { appearance }\end{array}$ & Body and texture & Spreadability & Flavour & $\begin{array}{c}\text { Overall } \\
\text { Acceptability }\end{array}$ \\
\hline $\mathbf{0} \%\left(\mathbf{W}_{0}\right)$ & $7.29^{\mathrm{b}} \pm 0.25$ & $7.02^{\mathrm{c}} \pm 0.10$ & $7.00^{\mathrm{c}} \pm 0.11$ & $7.08^{\mathrm{b}} \pm 0.05$ & $7.09^{\mathrm{bc}} \pm 0.11$ \\
\hline $\mathbf{5 \%}\left(\mathbf{W}_{1}\right)$ & $7.42^{\mathrm{b}} \pm 0.05$ & $7.10^{\mathrm{c}} \pm 0.11$ & $7.14^{\mathrm{c}} \pm 0.13$ & $7.58^{\mathrm{c}} \pm 0.06$ & $7.27^{\mathrm{c}} \pm 0.07$ \\
\hline $\mathbf{1 0} \%\left(\mathbf{W}_{2}\right)$ & $7.50^{\mathrm{b}} \pm 0.08$ & $7.43^{\mathrm{c}} \pm 0.15$ & $7.90^{\mathrm{d}} \pm 0.10$ & $7.40^{\mathrm{c}} \pm 0.13$ & $7.60^{\mathrm{d}} \pm 0.07$ \\
\hline $\mathbf{1 5} \%\left(\mathbf{W}_{3}\right)$ & $7.18^{\mathrm{b}} \pm 0.21$ & $6.52^{\mathrm{b}} \pm 0.13$ & $6.58^{\mathrm{b}} \pm 0.18$ & $7.11^{\mathrm{b}} \pm 0.12$ & $6.85^{\mathrm{b}} \pm 0.05$ \\
\hline $\mathbf{2 0} \%\left(\mathbf{W}_{4}\right)$ & $6.84^{\mathrm{a}} \pm 0.09$ & $5.99^{\mathrm{a}} \pm 0.24$ & $6.22^{\mathrm{a}} \pm 0.28$ & $6.53^{\mathrm{a}} \pm 0.15$ & $6.40^{\mathrm{a}} \pm 0.12$ \\
\hline $\mathbf{S E m}$ & 0.12 & 0.17 & 0.10 & 0.13 & 0.11 \\
\hline $\mathbf{C D}(\mathbf{P}<0.05)$ & 0.36 & 0.50 & 0.29 & 0.38 & 0.32 \\
\hline
\end{tabular}

* mean \pm SE of five replications within column followed by same letter are non-significantly different at $\mathrm{p}<0.05$.

Table.2 Effect of WPC on Physico-chemical properties of quarg cheese

\begin{tabular}{|c|c|c|c|c|c|c|}
\hline \multirow{2}{*}{ WPC level } & \multicolumn{7}{|c|}{ Physico-chemical properties } \\
& Fat (\%) & Protein $(\%)$ & Lactose $(\%)$ & Ash (\%) & TS (\%) & Acidity (\% LA) \\
\hline $\mathbf{0} \%\left(\mathbf{W}_{0}\right)$ & $13.00^{\mathrm{c}} \pm 0.32$ & $12.22^{\mathrm{a}} \pm 0.34$ & $2.10^{\mathrm{a}} \pm 0.17$ & $1.06^{\mathrm{a}} \pm 0.04$ & $26.82^{\mathrm{a}} \pm 0.83$ & $1.20^{\mathrm{a}} \pm 0.11$ \\
\hline $\mathbf{5} \%\left(\mathbf{W}_{1}\right)$ & $12.32^{\mathrm{b}} \pm 0.40$ & $15.51^{\mathrm{b}} \pm 0.12$ & $3.39^{\mathrm{b}} \pm 0.09$ & $1.37^{\mathrm{b}} \pm 0.11$ & $32.59^{\mathrm{b}} \pm 0.42$ & $1.51^{\mathrm{b}} \pm 0.04$ \\
\hline $\mathbf{1 0} \%\left(\mathbf{W}_{2}\right)$ & $11.91^{\mathrm{b}} \pm 0.35$ & $18.44^{\mathrm{c}} \pm 0.14$ & $4.45^{\mathrm{c}} \pm 0.09$ & $1.41^{\mathrm{b}} \pm 0.05$ & $36.54^{\mathrm{c}} \pm 0.42$ & $1.62^{\mathrm{b}} \pm 0.04$ \\
\hline $\mathbf{1 5} \%\left(\mathbf{W}_{3}\right)$ & $11.47^{\mathrm{a}} \pm 0.28$ & $21.37^{\mathrm{d}} \pm 0.16$ & $5.50^{\mathrm{d}} \pm 0.09$ & $1.64^{\mathrm{c}} \pm 0.04$ & $40.29^{\mathrm{d}} \pm 0.35$ & $1.73^{\mathrm{c}} \pm 0.04$ \\
\hline $\mathbf{2 0} \%\left(\mathbf{W}_{4}\right)$ & $10.59^{\mathrm{a}} \pm 0.44$ & $24.08^{\mathrm{e}} \pm 0.19$ & $6.57^{\mathrm{e}} \pm 0.10$ & $1.84^{\mathrm{d}} \pm 0.04$ & $43.97^{\mathrm{e}} \pm 0.33$ & $1.84^{\mathrm{c}} \pm 0.04$ \\
\hline SEm & 0.31 & 0.18 & 0.10 & 0.06 & 0.45 & 0.06 \\
\hline $\mathbf{C D}(\mathbf{P}<0.05)$ & 0.94 & 0.53 & 0.29 & 0.17 & 1.34 & 0.17 \\
\hline
\end{tabular}

* mean \pm SE of five replications within column followed by same letter are non-significantly different at $p<0.05$.

Table.3 Combine effect of ginger, cumin and their interaction on sensory attributes (score)* of quarg cheese

\begin{tabular}{|c|c|c|c|c|c|}
\hline Treatments & $\begin{array}{c}\text { Colour and } \\
\text { apperance }\end{array}$ & $\begin{array}{c}\text { Body and } \\
\text { texture }\end{array}$ & $\begin{array}{c}\text { Spreadabi } \\
\text { lity }\end{array}$ & Flavor & $\begin{array}{c}\text { Acceptabi } \\
\text { lity }\end{array}$ \\
\hline $\mathrm{C}_{1} \mathrm{G}_{1}$ & 7.25 & 7.62 & 7.83 & 7.62 & 7.78 \\
\hline $\mathrm{C}_{1} \mathrm{G}_{2}$ & 8.03 & 7.42 & 7.58 & 7.82 & 7.95 \\
\hline $\mathrm{C}_{1} \mathrm{G}_{3}$ & 7.22 & 6.48 & 6.95 & 7.30 & 7.57 \\
\hline $\mathrm{C}_{2} \mathrm{G}_{1}$ & 7.08 & 7.33 & 7.42 & 7.70 & 7.88 \\
\hline $\mathrm{C}_{2} \mathrm{G}_{2}$ & 6.75 & 7.05 & 7.22 & 7.50 & 7.90 \\
\hline $\mathrm{C}_{2} \mathrm{G}_{3}$ & 6.70 & 6.33 & 6.67 & 7.18 & 7.17 \\
\hline $\mathbf{M e a n}$ & $\mathbf{7 . 1 7}$ & $\mathbf{7 . 0 9}$ & $\mathbf{7 . 2 8}$ & $\mathbf{7 . 5 2}$ & $\mathbf{7 . 7 1}$ \\
\hline $\mathrm{CD}(\mathbf{P}<0.05) \mathrm{G}$ & 0.26 & 0.22 & 0.17 & 0.10 & 0.34 \\
\hline $\mathrm{CD}(\mathbf{P}<0.05) \mathrm{C}$ & 0.31 & 0.26 & 0.21 & $\mathrm{NS}$ & $\mathrm{NS}$ \\
\hline $\mathrm{CD}(\mathbf{P}<\mathbf{0 . 0 5} \mathbf{G} \mathbf{x} \mathrm{C}$ & 0.44 & $\mathrm{NS}$ & $\mathrm{NS}$ & 0.17 & $\mathrm{NS}$ \\
\hline
\end{tabular}

NS: Non significant 
Table.4 Combine effect of ginger and cumin on physico-chemical properties of quarg cheese

\begin{tabular}{|c|c|c|c|c|c|c|}
\hline Treatments & $\begin{array}{c}\text { Fat } \\
(\boldsymbol{\%})\end{array}$ & $\begin{array}{c}\text { Protein } \\
(\boldsymbol{\%})\end{array}$ & $\begin{array}{c}\text { Lactose } \\
(\boldsymbol{\%})\end{array}$ & $\begin{array}{c}\text { Ash } \\
(\boldsymbol{\%})\end{array}$ & $\begin{array}{c}\text { TS } \\
(\boldsymbol{\%})\end{array}$ & $\begin{array}{c}\text { Titrable acidity } \\
(\% \mathbf{L A})\end{array}$ \\
\hline $\mathrm{C}_{1} \mathrm{G}_{1}$ & 11.70 & 18.17 & 4.59 & 1.41 & 35.86 & 1.61 \\
\hline $\mathrm{C}_{1} \mathrm{G}_{2}$ & 11.66 & 18.14 & 4.57 & 1.50 & 35.86 & 1.63 \\
\hline $\mathrm{C}_{1} \mathrm{G}_{3}$ & 11.62 & 18.06 & 4.54 & 1.61 & 35.82 & 1.73 \\
\hline $\mathrm{C}_{2} \mathrm{G}_{1}$ & 11.76 & 18.40 & 4.57 & 1.47 & 36.19 & 1.61 \\
\hline $\mathrm{C}_{2} \mathrm{G}_{2}$ & 11.76 & 18.44 & 4.55 & 1.53 & 36.28 & 1.65 \\
\hline $\mathrm{C}_{2} \mathrm{G}_{3}$ & 11.83 & 18.43 & 4.53 & 1.66 & 36.45 & 1.74 \\
\hline $\mathrm{CD}(\mathbf{P}<0.05) \mathrm{G}$ & $\mathrm{NS}$ & $\mathrm{NS}$ & 0.03 & 0.02 & 0.06 & 0.02 \\
\hline $\mathrm{CD}(\mathbf{P}<0.05) \mathrm{C}$ & 0.03 & 0.08 & 0.04 & 0.03 & 0.07 & $\mathrm{NS}$ \\
\hline $\mathrm{CD}(\mathrm{P}<0.05) \mathrm{G} \times \mathbf{C}$ & 0.03 & $\mathrm{NS}$ & $\mathrm{NS}$ & $\mathrm{NS}$ & 0.09 & $\mathrm{NS}$ \\
\hline
\end{tabular}

NS: Non significant

Table.5 Changes in sensory attributes (score)* of quarg cheese with (GS) and without (CS) addition of ginger and cumin during storage

\begin{tabular}{|c|c|c|c|c|c|c|}
\hline $\begin{array}{c}\text { Sensory } \\
\text { attributes }\end{array}$ & \multicolumn{6}{|c|}{ Days } \\
\hline \multirow{4}{*}{$\begin{array}{l}\text { Colour and } \\
\text { appearance }\end{array}$} & Treatment & 0 & 5 & 10 & 15 & 20 \\
\hline & CS & $8.02 \pm 0.07$ & $7.72 \pm 0.02$ & $7.04 \pm 0.09$ & $4.5 \pm 0.08$ & -- \\
\hline & GS & $8.24 \pm 0.07$ & $7.78 \pm 0.09$ & $7.5 \pm 0.07$ & $7.14 \pm 0.08$ & $6.5 \pm 0.07$ \\
\hline & $\begin{array}{c}\mathrm{CD} \\
(\mathrm{P}<0.05)\end{array}$ & 0.19 & NS & 0.26 & 0.25 & \\
\hline \multirow{3}{*}{$\begin{array}{c}\text { Body and } \\
\text { texture }\end{array}$} & CS & $7.5 \pm 0.07$ & $7.11 \pm 0.03$ & $6.3 \pm 0.07$ & $5.4 \pm 0.07$ & -- \\
\hline & GS & $7.47 \pm 0.05$ & $7.3 \pm 0.05$ & $7.1 \pm 0.04$ & $6.1 \pm 0.04$ & $5.9 \pm 0.04$ \\
\hline & $\begin{array}{c}\mathrm{CD} \\
(\mathrm{P}<0.05)\end{array}$ & NS & 0.13 & 0.19 & 0.19 & \\
\hline \multirow{3}{*}{ Spreadability } & CS & $7.9 \pm 0.06$ & $7.3 \pm 0.09$ & $6.5 \pm 0.07$ & $6.1 \pm 0.03$ & -- \\
\hline & GS & $7.55 \pm 0.04$ & $7.1 \pm 0.04$ & $7.3 \pm 0.07$ & $5.8 \pm 0.07$ & $5.4 \pm 0.07$ \\
\hline & $\begin{array}{c}\mathrm{CD} \\
(\mathrm{P}<0.05)\end{array}$ & 0.17 & 0.23 & 0.23 & 0.17 & \\
\hline \multirow[t]{3}{*}{ Flavour } & CS & $7.4 \pm 0.03$ & $7.1 \pm 0.05$ & $6.8 \pm 0.03$ & $5.3 \pm 0.02$ & -- \\
\hline & GS & $7.9 \pm 0.04$ & $7.5 \pm 0.04$ & $7.3 \pm 0.06$ & $7.2 \pm 0.05$ & $5.9 \pm 0.06$ \\
\hline & $\begin{array}{c}\mathrm{CD} \\
(\mathrm{P}<0.05)\end{array}$ & 0.11 & 0.24 & 0.17 & 0.14 & \\
\hline \multirow{3}{*}{$\begin{array}{c}\text { Overall } \\
\text { acceptability }\end{array}$} & CS & $7.4 \pm 0.03$ & $6.9 \pm 0.06$ & $6.1 \pm 0.04$ & $5.5 \pm 0.03$ & -- \\
\hline & GS & $7.9 \pm 0.03$ & $7.2 \pm 0.05$ & $6.5 \pm 0.04$ & $6.2 \pm 0.02$ & $5.9 \pm 0.06$ \\
\hline & $\begin{array}{c}\mathrm{CD} \\
(\mathrm{P}<0.05)\end{array}$ & 0.11 & 0.24 & 0.21 & 0.07 & \\
\hline
\end{tabular}

* Mean \pm SE of five replication NS= Non-Significant (--) indicates that product was spoiled and no further analysis was carried out. 
Table.6 Changes in microbial load*of Quarg cheese with (GS) or without (CS) addition of ginger and cumin

\begin{tabular}{|c|c|c|c|c|c|c|}
\hline $\begin{array}{c}\text { Microbial } \\
\text { parameter }\end{array}$ & Treatment & \multicolumn{5}{|c|}{ Days } \\
\hline $\begin{array}{c}\text { SPC } \\
\mathrm{Log}_{10} / \mathrm{gm}\end{array}$ & CS & $1.73 \pm 0.01$ & $2.27 \pm 0.02$ & $3.16 \pm 0.02$ & $3.23 \pm 0.04$ & -- \\
\hline & GS & $1.64 \pm 0.02$ & $2.12 \pm 0.05$ & $2.94 \pm 0.02$ & $3.10 \pm 0.06$ & $3.19 \pm 0.08$ \\
\hline YMC & CD & 0.05 & 0.11 & 0.7 & NS & \\
\hline Cog & NIL & $0.21 \pm 0.04$ & $0.43 \pm 0.03$ & $1.23 \pm 0.02$ & - \\
\hline & GS & NIL & $0.10 \pm 0.04$ & $0.24 \pm 0.01$ & $1.11 \pm 0.03$ & $1.20 \pm 0.02$ \\
\hline CC & CD & NIL & NS & 0.07 & 0.12 & \\
\hline cfu/g & CS & NIL & NIL & $0.47 \pm 0.03$ & $0.59 \pm 0.01$ & - \\
& GS & NIL & NIL & $0.40 \pm 0.02$ & $0.48 \pm 0.03$ & $0.95 \pm 0.01$ \\
\hline & CD & NIL & NIL & NS & 0.07 & \\
\hline
\end{tabular}

$\mathrm{NS}=$ Non-Significant $*=$ means of $\pm \mathrm{SE}$ of five replication (--) indicates that product was spoiled and no further analysis was carried out

\section{Protocol for qurg cheese making}

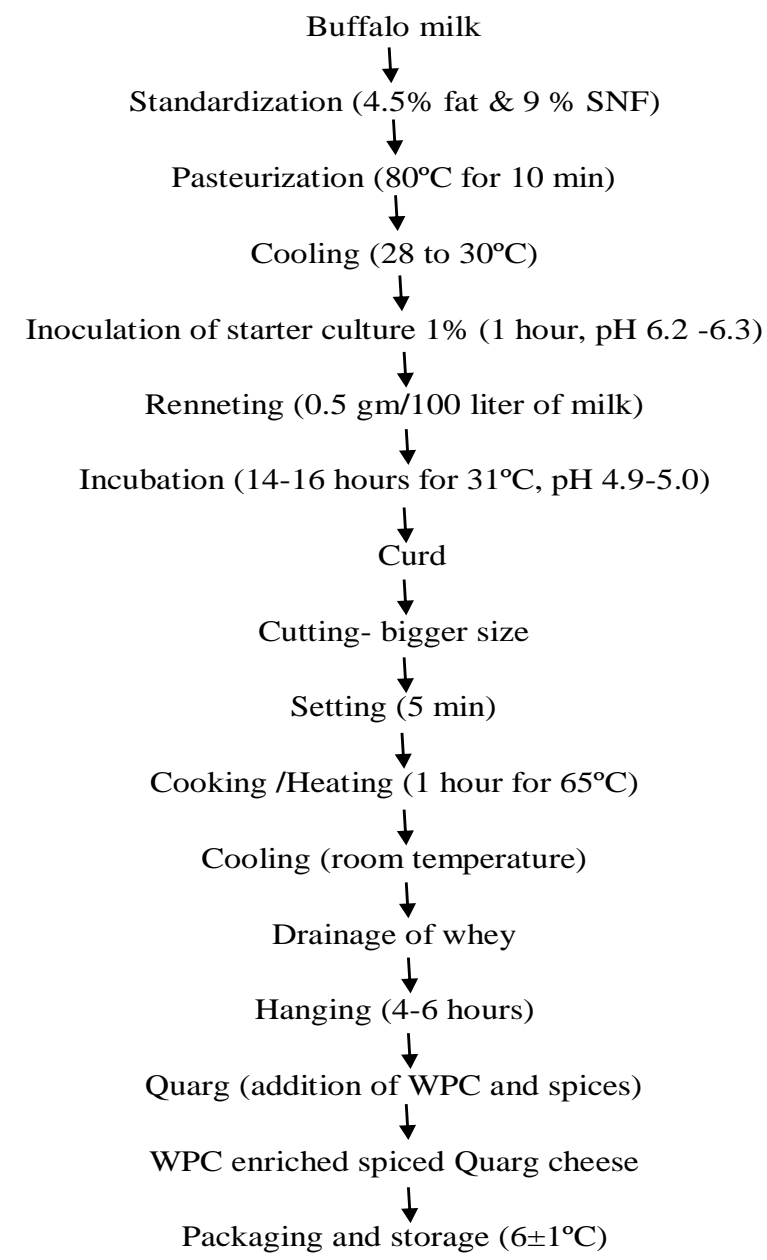


The highest total solid content was observed for quarg cheese prepared from $5 \%$ ginger and $2 \%$ cumin. As the ginger and cumin level increased, the total solids were also increased significantly $(\mathrm{p}<0.05)$. Quarg cheese prepared with ginger at $5 \%$ and cumin at $2 \%$ was recorded the highest titrable acidity in quarg cheese.

\section{Effect of storage on sensory attributes (score)* of quarg cheese}

The data in table 5 indicated that the as storage period increased the score of colour and appearance was decreased in both the quarg cheese. However the rate of decline was higher in CS than GS. Controlled sample was best up to 15 days while ginger and cumin added sample had acceptable color up to 20 days after that the color become slightly brown may be due to yeast and mould. Body and texture scores remained less unchanged up to ten days of storage in CS and GS. Thereafter, the addition of ginger and cumin was found to improve the flavour scores of the fresh quarg cheese, but sensory evaluation revealed that with advancing storage period, a gradual deterioration in flavour score was observed; thereafter it followed a rapid decrease in flavour score towards the end of storage period. The data showed that storage up to 5 days, no pronounced variation was observed amongst the samples pertaining to flavour, while up to 10 days, the control sample achieved lowest flavour score as compared to quarg with ginger and cumin. The data indicated that the overall acceptability of control sample was significantly lowered than the sample added with ginger and cumin.

\section{Changes in microbial quality}

The SPC count of quarg cheese blended with ginger and cumin on $15^{\text {th }}$ day was 3.10 $\log _{10} / \mathrm{gm}$ whereas quarg cheese prepared by without ginger and cumin was recorded highest count on $20^{\text {th }}$ days (3.23) (Table 6). Similarly in YMC, the minimum count was recorded in the ginger and cumin treated sample whereas maximum count was observed in control sample.

The maximum coliform count $(0.59 \mathrm{cfu} / \mathrm{g})$ was recorded in control sample on $15^{\text {th }}$ days, while the minimum $(0.48 \mathrm{cfu} / \mathrm{g})$ coliform count was recorded in ginger and cumin treated sample on $15^{\text {th }}$ day (Oladipo et al., 2013). Addition of WPC -70 at $10 \%$, ginger at $4 \%$ and cumin at $1 \%$ was found to be best in quality of quarg cheese.

As the storage period was increased the color and appearance, body texture, flavor, spreadabilty and overall acceptability was decreased. The results of SPC were indicated that the rate of growth of microorganism in control sample was significantly $(\mathrm{P}<0.05)$ faster than that of sample with ginger and cumin.

The results of YMC were showed that the average initial YMC in quarg cheese was nil in the entire sample.

\section{References}

A.O.A.C., 1995. Official methods of analysis, $16^{\text {th }}$ Edn. Association of Official Analytical Chemists, Washington, D.C., U.S.A.

Agrawal, A.K., Karkhele P. D., Karthikeyan S., Shrivastava A. and Geetesh Sinha 2016. Effect of variation of ginger juice on some physical and sensory properties of ice cream. Indian Journal of Dairy Science. 69(1): 17-23.

Amerine, M. A., Pangborn, R. M., \& Roessler, E. B. 2013. Principles of sensory evaluation of food. Academic Press. New York/London: 350-391.

Bhongle, P., Sabikhi, L., \& MH, S. K. 2016. An optimized process of Indian farmstead artisanal cheese: Value addition for increased farm income. Indian Journal of Dairy Science, 69(3): 252-258. 
Conforti, P. A., \& Lupano, C. E. 2004. Functional properties of biscuits with whey protein concentrate and honey. International journal of food science \& technology. 39(7): 745753.

David, J., 2006. "A book on Technological advances in market milk". Kitabmahal publication, Allahabad. Pp 30.

Dewani, P. P., \& Jayaprakasha, H. M. 2002. Effect of addition of whey protein concentrate on physico-chemical and sensory characteristics of Khoa and Khoa based sweets. Journal of food science and technology. 39(5):502-506.

Fox, P. F. 1993. Cheese: an overview. In Cheese: chemistry, physics and microbiology. Springer, Boston, MA. Pp. 1-36.

Hailu, Y., Seifu, E., \& Yilma, Z. 2014. Physicochemical properties and consumer acceptability of soft unripened cheese made from camel milk using crude extract of ginger (Zingiber officinale) as coagulant. African Journal of Food Science. 8(2): 87-91.

Hinrichs, J. 2001. Incorporation of whey proteins in cheese. International Dairy Journal. 11(47): 495-503.

Jayaprakasha, H. M. 2000. Final report of Adhoc research scheme, Whey protein concentrate in the formation of dairy and bakery products. Report submitted to Indian Council of Agricultural Research, New Delhi.

Menzies, J. 1988. Functional dairy ingredients for the catering pastery and baking ingredients. Food Australia. Pp 647 -650.
Munaza, B., Prasad, S. G. M., and Gayas, B. 2012. Whey protein concentrate enriched biscuits. International Journal of Scientific and Research Publications. 2(8): 1-4.

Narender Raju. 2004. Utilization of Whey Protein Concentrate in the Development of High Protein Bakery and Confectionery Products (Doctoral Dissertation, Acharya NG Ranga Agricultural University, Rajendranagar, Hyderabad).

Oladipo, I. C. and Jadesimi, P. D. 2012. Microbiological analysis and nutritional evaluation of West African soft cheese (wara) produced with different preservatives. Am J Food Nutr. 3(1): 13-21.

Pinto, S., Rathour, A. K., Prajapati, J. P., Jana, A. H., and Solanky, M. J. 2007. Utilization of whey protein concentrate in processed cheese spread. 6(7): 398-401.

Snedecor, G. W. and Cochran, W. G. 1989. Statistical Methods. Iowa State University Press, Ames, Iowa, Reprinted in 1994. East-West Press Pvt. Ltd., New Delhi.

Sudhir, V. K. 2002. Studies on improvement of quality of khoa using ultrafiltration technique (Doctoral dissertation, NDRI).

Thapa, T. B. and Gupta, V. K. 1996. Chemical and sensory qualities of processed cheese foods prepared with added whey protein concentrates. Indian journal of dairy science. 49(2): 129-137.

Yadav, R. S. 2016. Optimization of Processing Parameters and Extension of Shelf Life of 'Quark'-A Type of Thick Yoghurt. Sunsari Technical College Journal. 2(1): 38-43.

\section{How to cite this article:}

Patange D. D., S. V. Shinde, D. S. Chavan, D. K. Kamble and Memane C. V. 2018. Process Standardization of Whey Protein Enriched Spiced Quarg Cheese. Int.J.Curr.Microbiol.App.Sci. 7(06): 1349-1358. doi: https://doi.org/10.20546/ijcmas.2018.706.159 